\title{
PENGARUH PERBEDAAN PENAMBAHAN KONSENTRASI ANGGUR LAUT (Caulerpa racemosa) TERHADAP UJI ORGANOLEPTIK DAN UJI KIMIA PUDING ANGGUR LAUT
}

\author{
The Effect of Differences in Addition of Sea Grape Concentration (Caulerpa racemosa) to Organoleptic and \\ Chemical Test for Sea Grape Pudding \\ La Ode Aldin Manitaras, Moh. Nuh Ibrahim, Suwarjoyowirayatno \\ Jurusan Teknologi Hasil Perikanan, Fakultas Perikanan dan Ilmu Kelautan Universitas Halu Oleo, Kendari, \\ Sulawesi Tenggara, Indonesia \\ *Email korespondensi: aldinlaode93@gmail.com (Telp: 04013193596) \\ Diterima: 17 Juli / Disetujui 27 Agustus 2020
}

Cara sitasi: Manitaras LOA, Ibrahim MN, Suwarjoyowirayatno. 2020. Pengaruh perbedaan penambahan konsentrasi anggur laut (Caulerpa racemosa) terhadap uji organoleptik dan uji kimia puding anggur laut. Jurnal Fish Protech. 3(2):157164

\section{ABSTRACT}

The aims of this study was to determine the effect of increasing the concetration of sea grape on organoleptic value, chemical content and syneresis test content of sea grape pudding. This study used the completely randomized design (CRD) consisting of four treatments, $A$ (sea grape $16 \mathrm{~g}$ ), $B$ (sea grape $19 \mathrm{~g}$ ), $C$ (sea grape $22 \mathrm{~g}$ ) and $D$ (sea grape $25 \mathrm{~g}$ ). Analysis of organoleptic tests, chemical and syneresis test (AOAC method). The highest organoleptic test scores, appearance and the scent are present in treatment $A$ with a value of $4.38 \%$ and $4.48 \%$, a sense of the treatment of $C$ $4.18 \%$ and the texture of the treatment $D 4.31 \%$. The highest value of chemical content, moisture content in treatment $A$ with a value of $54.28 \%$, ash content, protein levels, carbohydrate levels and fiber content are found in $D$ treatment with grades $1.56 \%, 11.29 \%, 32.74 \%$ and $5.32 \%$. Respeetirely the highest syneresis test value is found in treatment $A$ with a value of $82,90 \%$. From Statistic real difference test (DMRT) shows that there are very real influence on moisture content, ash content, protein levels, carbohydrate content, fiber content and synerthetic test in sea grape pudding.

Keywords: Pudding, Sea Grapes, Chemical Content, Organoleptics, Syneresis

\begin{abstract}
ABSTRAK
Penelitian ini bertujuan untuk mengetahui pengaruh penambahan konsentrasi anggur laut terhadap nilai organoleptik, kandungan kimia dan kandungan uji sineresis puding anggur laut. Penelitian ini menggunakan Rancangan Acak Lengkap (RAL) yang terdiri empat perlakuan yaitu A (anggur laut $16 \mathrm{~g}$ ), B (anggur laut $19 \mathrm{~g}$ ), C (anggur laut $22 \mathrm{~g}$ ) dan $D$ (anggur laut $25 \mathrm{~g}$ ). Analisis uji organoleptik, kandungan kimia dan uji sineresis (metode AOAC). Nilai uji organoleptik tertinggi, rupa dan aroma terdapat pada perlakuan A dengan nilai $4,38 \%$ dan $4,48 \%$, rasa pada perlakuan C 4,18\% dan tekstur pada perlakuan D 4,31\%. Nilai kandungan kimia tertinggi, kadar air pada perlakuan A dengan nilai $54,28 \%$, kadar abu, kadar protein, kadar karbohidrat dan kadar serat terdapat pada perlakuan $D$ dengan nilai 1,56 , $11,29 \%, 32,74 \%$ dan $5,32 \%$. Nilai uji sineresis tertinggi terdapat pada perlakuan A dengan nilai $82,90 \%$. Dari statistik uji beda nyata (DMRT) menunjukan bahwa terdapat pengaruh sangat nyata pada kadar air, kadar abu, kadar protein, kadar karbohidrat, kadar serat dan uji sineresis pada puding anggur laut.
\end{abstract}

Kata kunci: Puding, Anggur Laut, Kandungan Kimia, Organoleptik, Sineresis

\section{PENDAHULUAN}

Rumput laut merupakan salah satu ganggang atau alga yang hidup di dasar perairan dengan topografi yang tidak begitu keras, tempat terlindung dari arus dan ombak yang kuat dan di area tersebut 
masih tergenang air pada pasang surut terendah antara 0,30-1 meter (Atmadja et al., 1991). Rumput laut ditemukan diperairan Sulawesi Tenggara khususnya di Desa Tanjung Tiram, Kecamatan Moramo, kabupaten Konawe Selatan. Salah satunya jenis rumput laut yang banyak terdapat di Desa Tanjung Tiram yaitu anggur laut (Caulerpa racemosa). Anggur laut termasuk rumput laut dari famili Caulerpaceae yang berasal dari kelas Chlorophyceae. Jenis rumput laut ini memiliki kandungan antioksidan dan bernilai ekonomi tinggi. Rumput laut jenis ini berpotensi untuk dibudidayakan. Namun saat ini produksinya rendah, masih bergantung pada alam, dan mengalami banyak kendala (Aslan, 1998).

Analisis fitokimia terhadap anggur laut segar dan rebus yang berfungsi sebagai antioksidan, setelah dilakukan diidentifikasi kandungan kimia bahwa komponen bioaktif anggur laut yang terdeteksi pada sampel segar yaitu steroid, flavonoid, fenol hidroquinon dan saponin, sedangkan pada sampel anggur laut rebus, komponen bioaktif yang terdeteksi adalah steroid, flavonoid, fenol hidroquinon dan saponin Asmara (2015). Anggur laut pada perkembangannya selain sebagai bahan makanan juga sudah banyak dimanfaatkan untuk keperluan medis (mengandung zat antioksidan) sehingga sangat baik untuk kesehatan (Verlaque et al., 2003). Ekstrak kasar anggur laut segar yang berasal dari Perairan Tual, Maluku Tenggara yang dilakukan oleh (Bagja, 2015), diperoleh kandungan vitamin $C$ segar dengan nilai $\mathrm{LC}_{50}$ yaitu $3,71 \mathrm{ppm}$, sementara penelitian yang dilakukan oleh (Tan dan Sou, 2001), diperoleh kandungan vitamin $\mathrm{C}$ pada anggur laut kering dengan nilai LC 5054.55 ppm.

Anggur laut ini tidak hanya dimanfaatkan untuk konsumsi sebagai bahan pangan tetapi juga telah dimanfaatkan sebagai bahan campuran obat anti

Pembuatan puding anggur laut Modifikasi metode (Oktari et al., 2017).

Pembuatan puding anggur laut dibuat dengan cara menimbang bahan-bahan yang diperlukan sesuai dengan formula yaitu $A$ (Anggur laut $16 \mathrm{~g}$ ), B (Anggur laut $19 \mathrm{~g}$ ), C (Anggur laut $22 \mathrm{~g}$ ) dan D (Anggur laut 25 jamur (Suhartini, 2003). anggur laut merupakan jenis rumput laut yang bisa dikosumsi dalam keadaan segar atau salad dengan rasa pedas, serta dimasak khusus untuk clavifera (Robledo dan Pelegrin, 1997). Oleh karena itu, diperlukan suatu tindakan diversifikasi produk olahan terhadap produk dari anggur laut untuk lebih berdaya guna mengoptimalkan pengolahan anggur laut menjadi suatu produk yang bergizi serta memberi nilai tambah dalam bentuk penghasilan bagi masyarakat, salah satu produk olahan yang dilakukan adalah puding anggur laut.

Puding adalah makanan yang terbuat dari hidrokoloid yang diolah dengan cara pemasakan dengan penambahan air sehingga menghasilkan tekstur yang lembut. Puding selain disajikan sebagai makanan pencuci mulut, juga disajikan sebagai makanan sajian utama (Webster, 1966 dalam Hayati, 2006). Puding merupakan hidangan penutup atau dessert yang banyak diminati oleh masyarakat indonesia karena rasanya yang manis, teksturnya lembut, dan proses pembuatannya yang relatif mudah dan cepat.

\section{METODE PENELITIAN \\ Alat dan Bahan}

Alat yang digunakan dalam penelitian ini yaitu baskom, blender (Miyako), timbangan analitik (M5$I O N)$, cetakan puding, panci, kompor (Miyako) dan stopwatch.

Bahan yang digunakan dalam penelitian ini yaitu anggur laut yang diambil di Desa Tanjung Tiram, Kecamatan Moramo, Kabupaten Konawe Selatan, susu cair (Frisian flag), gula tepung (Claris), kuning telur, pasta pandan, agar-agar (Nutrijell) dan air mineral (Aqua).

g). anggur laut, susu cair, gula halus, kuning telur, pasta pandang, agar-agar dan air diaduk hingga homogen dengan suhu pemasakan $100^{\circ} \mathrm{C}$. Pemasakan ini dilakukan selama \pm 15 menit hingga adonan mengental. Setelah proses pembuatan adonan puding selesai, adonan dicetak menggunakan cetakan puding ukuran $6,5 \mathrm{~cm}$. Setelah dilakukan 
pencetakkan kemudian didinginkan pada suhu ruang selama 15 menit sampai suhu panas pada puding menurun. Kemudian didinginkan pada lemari es dengan suhu $10^{\circ} \mathrm{C}$.

\section{Penilaian Organoleptik (Soekarto, 1985)}

Penilaian organoleptik terhadap produk puding anggur laut yang meliputi rupa, bau, rasa, dan tekstur dengan menggunakan format pengujian sensori. Pengujian ini menggunakan 20 orang panelis.

\section{Uji Kimia dan Uji Sineresis Puding Anggur Laut}

Analisis uji kimia puding anggur laut meliputi analisis kadar air, analisis kadar abu, analisis kadar protein, analisis kadar karbohidrat dan analisis kadar serat (AOAC, 2005). analisis kadar sineresis (Kuncari et al., 2014).

\section{Rancangan Penelitian}

Penelitian ini menggunakan Rancangan Acak Lengkap (RAL) yang terdiri dari empat perlakuan yaitu A (anggur laut $16 \mathrm{~g}$ ), B (anggur laut $19 \mathrm{~g}$ ), C (anggur laut $22 \mathrm{~g}$ ) dan $\mathrm{D}$ (anggur laut $25 \mathrm{~g}$ ). Masing-masing perlakuan dilakukan tiga kali ulangan, sehingga diperoleh jumlah satuan percobaan sebanyak 12 unit.

\section{Analisis Data}

Data dianalisis dengan menggunakan sidik ragam Analysis of Variance (ANOVA), jika terdapat pengaruh nyata terhadap variabel pengamatan, maka dilanjutkan dengan uji Duncan's Multiple Range Test (DMRT) pada taraf kepercayaan 95\% $(\alpha=0,05)$ (Steel and Torrie, 1995).

\section{HASIL DAN PEMBAHASAN}

\section{Hasil}

Hasil analisis sidik ragam produk puding anggur laut terhadap penilaian uji organoleptik yang meliputi rupa, bau, rasa, dan tekstur disajikan pada Tabel 1.

Tabel 1. Hasil analisis ragam dari uji organoleptik, uji kimia, dan uji sineresis puding anggur laut.

\begin{tabular}{|c|c|c|c|c|}
\hline \multirow[t]{2}{*}{ Parameter } & \multicolumn{3}{|c|}{ Perlakuan } & \multirow[b]{2}{*}{ D } \\
\hline & $\bar{A}$ & B & C & \\
\hline Nilai Organoleptik & $(\%) \pm S D$ & $(\%) \pm S D$ & $(\%) \pm \mathrm{SD}$ & $(\%) \pm S D$ \\
\hline Rupa & $4,38 \pm 0,07$ & $4,05 \pm 0,20$ & $4,25 \pm 0,05$ & $4,20 \pm 0,25$ \\
\hline Bau & $4,48 \pm 0,15$ & $3,08 \pm 0,12$ & $4,15 \pm 0,10$ & $4,01 \pm 0,02$ \\
\hline Rasa & $3,96 \pm 0,18$ & $4,08 \pm 0,18$ & $4,18 \pm 0,10$ & $4,15 \pm 0,25$ \\
\hline Tekstur & $4,10 \pm 0,15$ & $4,06 \pm 0,14$ & $4,10 \pm 0,15$ & $4,31 \pm 0,12$ \\
\hline \multicolumn{5}{|l|}{ Nilai Kimia } \\
\hline Kadar Air & $54,28 \pm 0,25^{a}$ & $53,22 \pm 0,14 \mathrm{bc}$ & $50,00 \pm 3,30^{b c}$ & $44,18 \pm 0,18^{d}$ \\
\hline Kadar Abu & $1,16 \pm 0,03$ a & $1,30 \pm 0,08$ bc & $1,45 \pm 0,03 c$ & $1,56 \pm 0,03^{c d}$ \\
\hline Kadar Protein & $6,93 \pm 0,62$ a & $7,76 \pm 0,18 b$ & $8,66 \pm 1,26 c$ & $11,29 \pm 0,81^{d}$ \\
\hline Kadar Karbohidrat & $24,09 \pm 0,09$ a & $26,58 \pm 0,68^{b}$ & $29,34 \pm 0,17 \mathrm{bc}$ & $32,74 \pm 1,05^{d}$ \\
\hline Kadar Serat & $2,58 \pm 0,22^{a}$ & $3,76 \pm 0,23 b$ & $4,48 \pm 0,30^{b c}$ & $5,32 \pm 0,32^{\text {cd }}$ \\
\hline Nilai Sineresis & $82,90 \pm 0,47$ a & $81,70 \pm 0,30 \mathrm{bc}$ & $79,74 \pm 0,94 c$ & $76,93 \pm 0,88^{d}$ \\
\hline
\end{tabular}


Berdasarkan data pada Tabel 1 menunjukkan bahwa pada puding dengan penambahan konsentrasi anggur laut yang berbeda meliputi rupa, bau, rasa dan tekstur tidak berpengaruh nyata terhadap uji organoleptik, sedangkan kadar air, kadar abu, kadar protein, kadar karbohidrat dan kadar serat berpengaruh sangat nyata terhadap uji kimia, dan uji sineresis berpengaruh sangat nyata.

\section{Sifat Organoleptik Rupa}

Hasil uji organoleptik terhadap rupa pada puding anggur laut menunjukkan nilai rerata tertinggi terdapat pada perlakuan $\mathrm{A}(16 \mathrm{~g})$ dengan nilai sebesar $4,38 \%$ sedangkan nilai rerata terendah terdapat pada perlakuan C $(19 \mathrm{~g})$ dengan nilai sebesar $4,05 \%$. Nilai uji organoleptik pada rupa dalam penelitian ini lebih rendah dari kualitas organoleptik puding rumput laut (Eucheuma cottonii) hasil penelitian Rosalita et al. (2018) yaitu $5,56 \%$. Hal ini diduga karena dalam pembuatan puding menggunakan anggur laut dengan konsentrasi yang berbeda yang menyebabkan warna pada puding menjadi sedikit berbeda. Hal ini didukung oleh Risfaheri et al. (2009) yang menyatakan bahwa perbedaan warna suatu makanan akibat bahan baku yang tidak seimbang. Anggur laut juga dapat berfungsi sebagai pewarna alami pada puding. Proses pembuatan puding pada penelitian ini menggunakan anggur laut segar, dimana warna yang dihasilkan tergolong cerah. Menurut Dwihandita (2009) warna anggur laut segar memiliki kenampakan cerah dan segar.

\section{Bau}

Hasil uji organoleptik terhadap bau pada puding anggur laut menunjukkan nilai rerata tertinggi terdapat pada perlakuan $\mathrm{A}(16 \mathrm{~g})$ dengan nilai sebesar $4,48 \%$, sedangkan nilai rerata terendah terdapat pada perlakuan $D(25 \mathrm{~g})$ dengan nilai sebesar $4,01 \%$. Nilai uji organoleptik pada aroma dalam penelitian ini lebih tinggi dari penambahan kalsium karbonat pada pembuatan tepung puding instan berbahan alginat hasil penelitian Fransiska et al. (2014) yaitu 4,33\%. Hal ini diduga karena pada perlakuan $\mathrm{A}(16 \mathrm{~g})$ persentase penambahan anggur laut lebih sedikit dimana anggur laut segar memiliki aroma yang cukup kuat dan dalam pembuatan puding menggunakan bahan tambahan susu cair dan pasta pandan, sehingga dapat mempengaruhi aroma puding yang dihasilkan. Hal ini sesuai dengan pernyataan Winarno (1996) yang menyatakan bahwa penambahan rumput laut sangat mempengaruhi aroma puding hal ini dikarenakan dalam pembuatan puding tersebut banyak komponen yang tercampur seperti susu cair dan pasta pandan yang dapat mengurangi aroma puding yang tidak terlalu kuat. Menurut Winarno (2002) yang menyatakan aroma pada makanan tidak hanya ditentukan oleh satu komponen tetapi oleh beberapa komponen tertentu yang menimbulkan bau yang khas dan dipengaruhi oleh perbandingan dari berbagai bahan yang digunakan.

\section{Rasa}

Hasil uji organoleptik terhadap rasa pada puding anggur laut menunjukkan nilai rerata tertinggi terdapat pada perlakuan $\mathrm{A}(16 \mathrm{~g})$ dengan nilai sebesar $4,30 \%$ sedangkan nilai rerata terendah terdapat pada perlakuan B $(19 \mathrm{~g})$ dengan nilai sebesar $3,08 \%$. Nilai uji organoleptik pada rasa dalam penelitian ini lebih rendah dari kualitas organoleptik puding rumput laut (Eucheuma cottonii) hasil penelitian Rosalita et al. (2018) yaitu 5,65\%. Hal ini diduga karena pada perlakuan $\mathrm{A}(16 \mathrm{~g})$ persentase penambahan anggur laut lebih sedikit dibandingkan dengan perlakuan $B$ (19 g), C (22 g) dan D (25 g). Semakin banyak konsentrasi anggur laut yang ditambahkan maka rasa khas anggur laut yang dihasilkan akan semakin terasa. Rasa dari anggur laut segar yaitu segar dan agak sedikit asin, sehingga mempengaruhi rasa produk puding yang dibuat. Hal ini sesuai dengan penelitian Dwihandita (2009) yang menyatakan bahwa manisan anggur laut dan acar anggur memiliki rasa manis, karena penambahan larutan gula pada anggur laut memberikan perubahan rasa yang signifikan. Menurut Maghfiroh (2000), salah satu faktor yang menentukan produk diterima atau tidak oleh konsumen adalah faktor rasa. Walaupun parameter penilaian yang lain 
baik, jika rasanya tidak disukai maka produk akan ditolak.

\section{Tekstur}

Hasil uji organoleptik terhadap tekstur pada puding anggur laut menunjukkan nilai rerata tertinggi terdapat pada perlakuan $\mathrm{D}(25 \mathrm{~g})$ dengan nilai sebesar $4,31 \%$ sedangkan nilai rerata terendah terdapat pada perlakuan B $(19 \mathrm{~g})$ dengan nilai sebesar $4,06 \%$. Nilai uji organoleptik pada tekstur dalam penelitian ini lebih rendah dari kualitas organoleptik puding rumput laut (Eucheuma cottonii) hasil penelitian Rosalita et al. (2018) yaitu 5,86\%. Hal ini diduga karena persentase penambahan anggur laut yang lebih banyak. Anggur laut mengandung kadar air yang cukup tinggi sehingga dapat mempengaruhi tekstur puding yang dihasilkan menjadi kenyal dan kuat. Menurut Dwihandita (2009) yang menyatakan bahwa kandungan air anggur laut segar masih tinggi sehingga kandungan cairan dalam jaringan tubuh masih besar yang membuat tekstur anggur laut segar kenyal dan kuat.

\section{Sifat Kimia}

\section{Kadar Air}

Hasil uji kimia terhadap kadar air pada puding anggur laut menunjukkan nilai rerata tertinggi terdapat pada perlakuan $\mathrm{A}(16 \mathrm{~g})$ dengan nilai rerata $54,28 \%$, sedangkan nilai rerata terendah terdapat pada perlakuan D $(25 \mathrm{~g})$ dengan nilai rerata $44,18 \%$. Nilai kadar air dalam penelitian ini lebih tinggi dibandingkan kadar air permen jelly caulerpa sp. Hasil penelitian Lewerissa (2017) yaitu 33,99\%. Hasil penelitian menunjukan bahwa kadar air puding anggur laut mengalami penurunan pada perlakuan $\mathrm{D}(25 \mathrm{~g})$. Hal ini diduga karena penambahan konsentrasi anggur laut dapat menurunkan nilai kadar air puding anggur laut. Hal ini sesuai dengan penelitian Dwihandita (2009) bahwa anggur laut segar memiliki rata-rata kadar air tertinggi dan lebih dari $80 \%$ diduga karena anggur laut segar tidak mengalami pengolahan lebih lanjut sehingga kandungan air dalam bahan tidak mengalami banyak perubahan. Menurut Kusumah et al. (2002), jumlah air yang ditambahkan maupun yang terkandung pada bahan penyusun berpengaruh terhadap kadar air puding yang dihasilkan.

\section{Kadar Abu}

Hasil uji kimia terhadap kadar abu pada puding anggur laut menunjukkan nilai rerata tertinggi terdapat pada perlakuan $\mathrm{D}(25 \mathrm{~g})$ dengan nilai rerata $1,55 \%$, sedangkan nilai rerata terendah terdapat pada perlakuan $A(16 \mathrm{~g})$ dengan nilai rerata $1,16 \%$. Nilai kadar abu pada penelitian ini lebih rendah dari kadar abu produk variasi rasio tomat dan tepung rumput laut hasil penelitian Lukito et al., (2017) yaitu 1.69\%. Hal ini diduga karena kadar abu yang terkandung di dalam anggur laut yang digunakan cukup tinggi. Hal ini sesuai penelitian yang dilakukan oleh Idham et al. (2018) bahwa kandungan kadar abu lebih tinggi diduga karena anggur laut yang digunakan mempunyai kandungan mineral yang cukup tinggi. Yani (2006), menyatakan bahwa rumput laut memiliki kandungan mineral yang cukup tinggi. Semakin rendah nilai kadar abu maka kandungan mineral pada bahan semakin sedikit (Panggalih, 2010). Nilai kadar abu suatu bahan pangan menunjukkan besarnya jumlah mineral yang terkandung dalam suatu bahan pangan tersebut (Apriyantono, 1989).

\section{Kadar Protein}

Hasil uji kimia terhadap kadar protein pada puding anggur laut menunjukkan nilai rerata tertinggi terdapat pada perlakuan $\mathrm{D}(25 \mathrm{~g})$ dengan nilai rerata $11,29 \%$, sedangkan nilai rerata terendah terdapat pada perlakuan $\mathrm{A}(16 \mathrm{~g})$ dengan nilai rerata $6,93 \%$. Nilai kadar protein pada penelitian ini lebih rendah dari kadar protein tertinggi pada produk tepung puding instan alginat dari hasil penelitian Fransiska et al., (2014) yaitu $3,67 \%$. Hal ini diduga karena susu cair sebagai bahan tambahan pada puding anggur laut memiliki kandungan protein yang cukup tinggi yaitu $80 \%$ (Winarno, 1993), selain itu penambahan anggur laut mampu meningkatkan kadar protein puding. Menurut Verlaque et al. (2003) yang menyatakan bahwa kadar protein yang terkandung pada anggur laut yaitu 2,7\%. Menurut Lukito et al. (2017) yang menyatakan bahwa semakin banyak 
penambahan rumput laut pada pembuatan dodol maka akan menghasilkan kadar protein yang lebih tinggi.

\section{Kadar Karbohidrat}

Berdasarkan hasil rerata kadar karbohidrat puding anggur laut dengan penambahan konsentrasi anggur laut yang berbeda menunjukkan bahwa nilai kadar karbohidrat pada masing-masing perlakuan $\mathrm{A}$ (16 g) 24,09\%, B (19 g) 26,58\%, C (22 g) 29,34\% dan D (25 g) $32,74 \%$, Hasil uji kimia terhadap kadar karbohidrat pada puding anggur laut menunjukkan nilai rerata tertinggi terdapat pada perlakuan $\mathrm{D}(25 \mathrm{~g})$ dengan nilai rerata $32,74 \%$, sedangkan nilai rerata terendah terdapat pada perlakuan $\mathrm{A}(16 \mathrm{~g})$ dengan nilai rerata $24,09 \%$. Nilai kadar karbohidrat dalam penelitian ini lebih rendah dari kadar karbohidrat pada produk penambahan kalsium karbonat pada pembuatan tepung puding instan berbahan alginat hasil penelitian Fransiska et al. (2014) yaitu 78,28\%. Hal ini diduga karena persentase penambahan anggur laut yang lebih banyak. Hal ini sesuai dengan pendapat Verlaque et al. (2003) yang menyatakan bahwa kadar karbohidrat yang terkandung dalam anggur laut segar yaitu sebanyak $8,47 \%$.

\section{Kadar Serat}

Hasil uji kimia terhadap kadar serat pada puding anggur laut menunjukkan nilai rerata tertinggi terdapat pada perlakuan $D(25 \mathrm{~g})$ dengan nilai rerata $5,32 \%$, sedangkan nilai rerata terendah terdapat pada perlakuan $\mathrm{A}(16 \mathrm{~g})$ dengan nilai rerata $2,58 \%$. Nilai kadar serat pada penelitian ini lebih tinggi dari kadar serat tertinggi produk jelly drink rumput laut dari hasil penelitian (Wati dan Ida, 2015) yang sebesar $0,44 \%$. Hal ini diduga karena anggur laut pada perlakuan $A$ $(25 \mathrm{~g})$ lebih tinggi, dimana rumput laut memiliki kandungan serat yang cukup tinggi. Menurut Lukito (2017), rumput laut Eucheuma cottoni sebagai penghasil karaginan mempunyai kandungan serat yang tinggi. Berbeda dengan penelitian yang dilakukan oleh Astawan et al., (2004) bahwa kadar serat dodol rumput laut mempunyai nilai yang lebih tinggi yaitu $6,20 \%$, dibandingkan dengana perlakuan $\mathrm{A}$. Hal ini disebabkan tingginya kadar serat pada dodol rumput laut disebabkan pada formula dodol rumput laut tepung ketan diganti dengan bubur rumput laut yang kadar seratnya lebih tinggi $13.98 \%$ (bb) dibandingkan tepung ketan dengan kadar serat 2.1-5.3 \% (bb).

\section{Sifat Sineresis}

Hasil uji sineresis pada puding anggur laut penyimpanan selama 24,48 dan 72 jam menunjukkan nilai rerata tertinggi terdapat pada perlakuan $\mathrm{A}(16 \mathrm{~g})$ dengan nilai rerata $82,90 \%$, sedangkan nilai rerata terendah terdapat pada perlakuan $\mathrm{D}(25 \mathrm{~g})$ dengan nilai rerata $76,93 \%$. Nilai sineresis dalam penelitian ini lebih tinggi dari sineresis pada sediaan gel yang mengandung minoksidil, apigenin dan perasan herba seledri hasil penelitian (Kuncari et al., 2014) yaitu $17,79 \%$. Hal ini diduga karena proses keluarnya air atau rembesan cairan pada puding anggur laut selama penyimpanan dingin lebih sedikit, penambahan anggur laut dapat menurunkan kadar sineresis puding anggur laut. Hal ini sesuai dengan pendapat (Tapotubun, 2018) menyatakan bahwa tingkat sineresis gel akan semakin berkurang dengan adanya karbohidrat/polisakarida yang berasal dari anggur laut. Subaryono et al, (2010) menyatakan bahwa semakin tinggi ikatan yang terjadi maka daya tarik antar molekul polisakarida - alginat semakin kuat, sehingga tingkat sineresis lebih rendah/kecil.

\section{KESIMPULAN}

Berdasarkan hasil dan pembahasan, maka dapat disimpulkan sebagai berikut:

1. Penambahan anggur laut dengan konsentrasi berbeda pada nilai organoleptik puding anggur laut menunjukan tidak berpengaruh nyata terhadap kenampakan, aroma, rasa dan tekstur.

2. Terdapat pengaruh sangat nyata terhadap kandungan kimia puding anggur laut. Perlakuan $\mathrm{A}$ memiliki nilai kadar air tertinggi yaitu $54,28 \%$, dan pada perlakuan $\mathrm{D}$ memiliki nilai tertinggi pada kadar abu $1,55 \%$, kadar protein $11,29 \%$, kadar karbohidrat 32,74\%, dan kadar serat 5,32\%.

3. Terdapat pengaruh sangat nyata terhadap uji sineresis puding anggur laut. Nilai rerata tertinggi 
sineresis terdapat pada perlakuan $\mathrm{A}(16 \mathrm{~g})$ dengan nilai $82,90 \%$.

Hasil uji sensorik kenampakkan pada kerupuk didapatkan nilai rerata tertinggi terletak pada perlakuan P4 sebesar 7,3 dan nilai rerata terendah terletak pada perlakuan P1 sebesar 6,7. Hasil uji sensorik menunjukkan bahwa perbandingan ikan layang dan rumput laut pada pembuatan kerupuk tidak mempengaruhi nilai organoleptik pada kenampakannya. Secara garis besar kenampakan pada kerupuk ikan menunjukkan hasil yaitu rapi, bersih, kurang homogen, ketebalan kurang rata, warna agak kecoklatan. Warna kecoklatan pada kerupuk disebabkan oleh adanya reaksi browning non enzimatis (reaksi maillard) setelah digoreng. Reaksi maillard terjadi karena adanya asam amino lisin dan glukosa yang bereaksi pada suhu tinggi sehingga menghasilkan senyawa melanoidin yang membuat bahan berwarna coklat (Winarno, 1992). Menurut Abubakar (2009) asam amino lisin berasal dari pemecahan struktur heliks dan ikatan peptida kolagen akibat pemanasan secara bertahap.

\section{DAFTAR PUSTAKA}

AOAC. 2005. Offivall MethodPs of Analysis. 18th ed. Association of Offical Analytical Chemists, Washington DC.

Apriyantono, D. F.A. 1989. Petunjuk Laboratorium Analisis Pangan.Departemen Pendidikan dan Kebudayaan Direktorat Jenderal Pendidikan Tinggi Pusat Antar Universitas Pangan dan Gizi IPB. Bogor.

Aslan. (1998). Budidaya Rumput Laut. Yogyakarta: Penerbit Kanisius.

Asmara, DA. 2015. Kandungan Senyawa Fenol Anggur Laut (Caulerpa sp.) Segar dan Rebus dari Perairan Tual, Maluku. Departemen Teknologi Hasil PerairanFakultas Perikanan dan IImu Kelautan. IPB.

Astawan DA., Sutrisno K., dan Fanie H. 2004. Pemanfaatan Rumput Laut (Eucheuma cottonii) untuk Meningkatkan Kadar lodium dan Serat Pangan pada Selai dan Dodol.Vol. XV Nomor 1. Teknologi dan Industri Pangan. IPB Darmaga Bogor.

Atmadja, PS. Kadi A, Sulistijo, Satari R. 1991. Pengenalan Jenis-Jenis Rumput Laut Indonesia. Jakarta: Puslitbang Oseanologi LIPI.

Bagja, AP. 2015. Aktivitas Antioksidan Rumput Laut Caulerpa sp. Segar dan Rebus. [Skripsi]: Bogor. Institut Pertanian Bogor.

Dina fransiska, Annisa I, P, dan Sakina H, 2014. Penambahan Kalsium Karbonat Pada Pembuatan Tepung Instan Berbahan Alginat. Balai Besar Penelitian dan
Pengembangan Pengolahan Produk dan Bioteknologi Kelautan dan Perikanan.

Draget, K.I, Gåserød, O., Aune, I., Anderse, P.O., Storbakken, B, Stoke, B.T., \& Smidsrød, O. (2001). Effects Of Molecular Weight and Elastic Segment Flexibility On Syneresis In CaAlginate Gels. Food Hydrocolloids. (15): 485-490

Dwihandita, N. 2009. Perubahan Kandungan Antioksidan Anggur Laut (Caulerpa. racemosa) Akibat Pengolahan [Skripsi]. Fakultas Perikanan dan IImu Kelautan Institut Pertanian Bogor, Bogor. 97 hal.

Kuncari, E.S., Iskandarsyah, dan Praptiwi. 2014. Evaluasi, Uji Stabilitas Fisik dan Sineresis Sediaan Gel Yang Mengandung Minoksidil, Apigenin, dan Perasan Herba Seledri (Apium graveolens L.).

Idham, N.P., Isamu, K.T, dan Suwarjoyowirayatno. 2018. Analisis Organoleptik, dan Kandungan Kimia Permen Jelly Anggur Laut (Caulerpa racemosa).

Kusumah, F. C, Maheswari, R. R. A. dan Wulandari, Z. 2002. Standarisasi Suhu Pemanasan Pada Proses Pengolahan Dodol Susu. Med Perternakan. 25:75-83.

Latimer, G. (editor). Official Methods of Analysis of AOAC Internasional, 19th Edition; 2012.

Lawerissa V. J, 2017. Karasteristik Fisik Dan Kimia Permen Jelly (Caulerpa SP.). SKRIPSI SRATA 1. Fakultas Perikanan dan IImu Kelautan, Universitas Pattimura. 
Lukito, M.S., Giyarto, dan Jayus 2017. Sifat Fisik, Kimia Dan Organoleptik Dodol Hasil Variasi Rasio Tomat Dan Tepung Rumput Laut. Fakultas Teknologi Pertanian, Universitas Jember.

Maghfiroh, I. 2000. Pengaruh Penambahan Bahan Pengikat terhadap Karakteristik Nugget Ikan Patin (Pangasius pangasius). [Skripsi]. Fakultas Perikanan dan IImu Kelautan. Program Studi Teknologi Hasil Perikanan, Institut Pertanian Bogor.

Oktari, A. Ira S. dan Dewita. 2017. Pengaruh Penambahan Sari Pati Pandan (Pandanus Amaryllifolius) pada Pembuatan Puding Karaginan. [Jurnal] Vol. 5. Bidang Perikanan dan IImu Kelautan. Universitas Riau.

Panggalih, A. I. 2010. Pengaruh jenis Kemasan dan Suhu Penyimpanan Pada Umur Simpan Teh Hijau. [Skripsi]. Bogor: Institut Pertanian Bogor.

Risfaheri, T., Hidayat, N., Nurdjannah., dan M.P. Laksmanahardja. 2009. Inovasi teknologi pengolahan lada. Makalah anugerah kekayaan intelektual luar biasa No. 22059198: Bidang Teknologi Subbidang Pangan. Balai Besar Penelitian dan Pengembangan Pascapanen Pertanian, Bogor. hlm.33.

Rosalita., Syam, H., Fadhilah, R. 2018. Terhadap Kualitas Organoleptik Puding Rumput Laut (eucheuma cottonii). Alumni Program Studi Pendidikan Teknologi Pertanian dan Dosen PTP FT UNM.

Robledo, D. and Y. F. Pelegrín. 1997. Chemical and Mineral Composition of Six Potentially Edible Seaweed Species of Yucatán. Botanica Marina Vol. 40. 1997. pp. 301 306. Walter de Gruyter. Berlin. New York.

Soekarto, ST. 1985. Penilaian Organoleptik untuk Industri Pangan dan Hasil Pertanian. Jakarta: Bharata Karya Aksara.

Standar Nasional Indonesia untuk Puding. SNI 7388:2009. [online] tersedia di http://sisni.bsn.go.id/index.php/sni/Sni/top 10download_sni.

Steel, R. G. D. and J. H. Torrie. 1995. Principles and procedures of statistics. Alih Bahasa Sumantri, B. Prinsip dan Prosedur
Statistika. Edisi 4 Penerbit P. T. Gramedia Pustaka Utama, Jakarta.

Suhartini, S. 2003. Penapisan awal Caulerpa racemosa, Sesuvium portulacastrum, Xylocarpus granatum dan Ulva lactuca Sebagai Antimikroba. [Skripsi]. Bogor: Program Studi Teknolog.

Subaryono., Peranginangin, R., Fardiaz, D., \& Kusnandar, F. (2010). Pembentukan Gel Alginat yang Diekstrak dari Sargassum filipendula dan Turbinaria decurrens Menggunakan $\mathrm{CaCO} 3$ dan Glucono- $\delta$ lactone (GDL). Jurnal Pasca panen dan Bioteknologi Kelautan dan Perikanan. (5): 43-54.

Tan, R.X., and W.X. Zou. 2001. Endophytes : a rich source of functional metabolites. Nat. Prod. Rep. 18: 448-459.

Tapotubun, A.M. 2018. Komposisi Kimia Rumpu laut (Caulerpa lentillifera) Dari Perairan Kei Maluku Dengan Metode Pengeringan Berbeda. JPHPI. Volume 21. Nomor 1. DOI: 10.17844/jphpi.v21il.21257.

Verlaque, M., Durand C, Huisman JM, Bouduresque, CF, Le Parco Y, 2003. On Identity and Origin of The Mediterranen Invasive $C$. racemosa, European Journal of Physocology.

Wati, I., dan Ida, A. S. 2015. Penggunaan Rumput Laut (Eucheuma cottonii) Sebagai Pengganti Karagenan Dalam Pembuatan Jelly Drink Rosella (Kajian Konsentrasi Rumput Laut Dan Karagenan). Vol. 12, No. 1.

Webster, N. 1966. Webster 3 rd New International Dictionary. USA: $G$ and $C$ Merriem Co Pub.

Winarno, F. G. 1993. Pangan, Gizi, Teknologi, dan Konsumen. PT. Gramedia Pustaka Utama, Jakarta.

1996. Teknologi Pengolahan Rumput Laut. Pustaka Sinar Harapan, Jakarta. $103 p$ 2002. Teknologi Pengolahan Gula Pasir. Pustaka Gramedia. Jakarta.

Yani, H, I. 2006. Karakteristik Fisika Kimia Permen Jelly dari Rumput Laut Eucheuma spinosum dan Eucheuma cottonii. [Skripsi]. Bogor: InstitutPertanian Bogor. 